Errata

\title{
Erratum to: "Petrology and geochemistry of the Tertiary alkaline intrusive rocks at Doupov, Doupovské hory Volcanic Complex (NW Bohemian Massif)" Journal of Geosciences 55: 251-278
}

\section{František V. HOLUB ${ }^{1}$, Vladislav RAPPRICH², Vojtěch ERBAN ${ }^{2, *}$, Zoltán PÉCSKAY³, Bedřich MLČOCH², Jitka MíKOVÁ2}

${ }^{1}$ Institute of Petrology and Structural Geology, Faculty of Science, Charles University in Prague, Albertov 6, 128 43 Prague 2, Czech Republic; frholub@natur.cuni.cz

${ }^{2}$ Czech Geological Survey, Klárov 3, 11821 Prague 1, Czech Republic; vojtech.erban@geology.cz

${ }^{3}$ Institute of Nuclear Research, Hungarian Academy of Sciences, Bem tér 18/C, H-4001 Debrecen, Hungary

* Corresponding author

Received: 6 October 2012; accepted: 6 October 2012; handling editor: V. Janoušek

In the Tab. 5 of the original article the initial ${ }^{143} \mathrm{Nd} /{ }^{144} \mathrm{Nd}$ ratios printed were erroneously calculated for age significantly higher than the declared $30 \mathrm{Ma}$. The table with corrected $\left({ }^{143} \mathrm{Nd} /{ }^{144} \mathrm{Nd}\right)_{30}$ values is presented below. Please note that all other references to $\mathrm{Sr}$ and $\mathrm{Nd}$ isotopic values in the article are correct (i.e. in the text and in the Fig. 11).

Tab. $5 \mathrm{Sr}-\mathrm{Nd}$ isotopic data for the studied alkaline intrusive rocks

\begin{tabular}{|c|c|c|c|c|c|c|}
\hline Sample & DH1330 & DR051B & TV52 & TV54 & DH1321 & DH745 \\
\hline Rock type & Melteigite & Urtite & Essexite & $\begin{array}{c}\text { Sodalite } \\
\text { monzosyenite }\end{array}$ & $\begin{array}{c}\text { Metasom. r. } \\
\text { "Pseudolamprophyre" }\end{array}$ & $\begin{array}{c}\text { Haüyne-phyric } \\
\text { phonolite }\end{array}$ \\
\hline${ }^{87} \mathrm{Sr} /{ }^{86} \mathrm{Sr}$ (measured) & 0.703823 & 0.703608 & 0.704384 & 0.705060 & 0.704241 & 0.703884 \\
\hline 1 sigma & 0.000066 & 0.000078 & 0.000068 & 0.000063 & 0.000082 & 0.000037 \\
\hline $2 \mathrm{~S}(\mathrm{M})$ & 0.000010 & 0.000015 & 0.000013 & 0.000009 & 0.000016 & 0.000010 \\
\hline${ }^{143} \mathrm{Nd} /{ }^{144} \mathrm{Nd}$ (measured) & 0.512793 & 0.512789 & 0.512729 & 0.512694 & 0.512811 & 0.512722 \\
\hline 1 sigma & 0.000045 & 0.000061 & 0.000040 & 0.000065 & 0.000052 & 0.000039 \\
\hline $2 \mathrm{~S}(\mathrm{M})$ & 0.000011 & 0.000011 & 0.000009 & 0.000019 & 0.000013 & 0.000008 \\
\hline$\left({ }^{87} \mathrm{Sr} /{ }^{86} \mathrm{Sr}\right)_{30}$ & 0.703766 & 0.703577 & 0.704283 & 0.704866 & 0.704029 & 0.703787 \\
\hline$\left({ }^{143} \mathrm{Nd} /{ }^{144} \mathrm{Nd}\right)_{30}$ & 0.512770 & 0.512771 & 0.512708 & 0.512676 & 0.512788 & 0.512713 \\
\hline
\end{tabular}

$\left({ }^{87} \mathrm{Sr} /{ }^{86} \mathrm{Sr}\right)_{30}$ and $\left({ }^{143} \mathrm{Nd} /{ }^{144} \mathrm{Nd}\right)_{30}$ are initial ratios corrected to the mean age of $30 \mathrm{Ma}$

$2 \mathrm{~S}(\mathrm{M})$ - two standard errors of the mean 